\title{
"Making a Message Book" may contribute to peaceful death for terminally ill cancer patients
}

\author{
Michiyo Ando ${ }^{1 *}$, Yosuke Uchitomi ${ }^{2-4}$, Shigeru Hayashida ${ }^{5}$ and Hiromi Minoda ${ }^{6}$ \\ ${ }^{1}$ St. Mary's College, Japan \\ ${ }^{2}$ Innovation Center for Supportive, Palliative and Psychosocial Care, National Cancer Center Hospital, Japan \\ ${ }^{3}$ Department of Psycho-Oncology, National Cancer Center Hospital, Japan \\ ${ }^{4}$ Center for Public Health Sciences, National Cancer Center, Japan \\ ${ }^{5}$ Naito Hospital, Japan \\ ${ }^{6}$ St. Mary's Hospital, Japan
}

\section{Summary}

A peaceful death is one of the most important themes in palliative care. The aim of this study was to show the cases in which a "Making a Message Book" approach was useful for terminally ill cancer patients for promoting peaceful death. "Making a Message Book" is a new idea for a psychological approach for terminally ill patients, in which the patients tell or write down what they want to tell to important people using sentence and art with a clinical psychologist. In Case 1 , although the patient wanted to talk about her death with children, she could not do it directly. Then, she participated in the study of "Making a Message Book;" she could express her emotion and thoughts and became happy. In Case 2, a patient was conscious to her near death. So she participated in "Making a Message Book" to tell grandchildren what she want to tell in future. After completing it, she was relaxed. Both patients could write what they wanted to tell to important people and could attain their roles. These results suggest that "Making a Message Book" may contribute to promote peaceful death for Japanese terminally ill patients.

\section{Introduction}

One of the important goals in palliative care is to promote a peaceful death. Peaceful death is a concept that means accepting death, being at peace, being comfortable. Based on a quantitative survey conducted in Japan, Miyashita et al. [1] clarified the concepts that Japanese people perceive as important for a peaceful death. They identified 18 domains that contributed to a peaceful death. The ten domains classified as consistently important domains were "physical and psychological comfort," "dying in a favorite place," "good relationship with medical staff," "maintaining hope and pleasure," "not being a burden to others", "good relationship with family," "physical and cognitive control," "environmental comfort," "being respected as an individual," and "life completion." Moreover, they identified eight domains with mixed importance, such as "natural death," "preparation for death," "role accomplishment and contributing to others," "unawareness of death," "fight against cancer," "pride and beauty," "control over the future," and "religious and spiritual comfort."

"Role accomplishment and contributing to others" is one of the most important domains. Dignity psychotherapy [2,3] was useful to express patients' emotions or thoughts. In this therapy, patients talk about their life as legacy. Though it is useful, however, culturally, some terminally ill cancer patients cannot express their mind or thoughts directly as legacy. In order to express emotions or thoughts, we developed a new psychotherapy called "Making a Message Book". In this approach, patients express what they want to say to important persons using messages, and sometimes with drawings. We experienced cases in which this therapy might be useful to attain their roles, and reported.

\section{Case studies}

\section{Case 1}

Patient A: Patient A was in the general hospital. She was 60 years old. She was a terminally ill cancer patient. She had two daughters and a husband.

Procedure: She had a strong anxiety towards the future, so the physicians introduced a clinical psychologist. She agreed to participate in the research. The patient and the clinical psychologist met three times as an interviewer, once a week and performed "Making a message book."

Making a message book: We call "Making a Message Book" as a therapy in which patients write messages using sentences or drawings in order to express what they want to say. There are two kinds of performance. If a patient can do the task by themselves, an interviewer watches them. If a patient cannot make the book by themselves, patients with low physical strength, the interviewer listens to messages from the patient, and helps to make the book (Table 1).

Ethical consideration: This study is approved from the institutions of the researchers. This study is conducted as a part of an art therapy study.

\section{Interview sessions:}

Session 1: The patient had lung cancer and she had pain when she breathed. However, she could still talk to the interviewer. Her husband was retired; her eldest daughter worked at a company; and her second daughter was a college student. The patient's physical condition was

Correspondence to: Michiyo Ando, St. Mary's Hospital, 422 Tusbukuhonmachi, Kurume, Fukuoka, Japan, Tel: 830-8543; E-mail: andou@st-mary.ac.jp

Key words: terminally ill patients, message book, peaceful death

Received: November 10, 2016; Accepted: November 26, 2016; Published: November 29, 2016 
Table 1. Contents of Making a Message Book.

\begin{tabular}{|c|c|}
\hline Times & Contents \\
\hline $\begin{array}{l}\text { The interview } \\
\text { session was } 2 \text { or } 3 \text { times } \\
\text { at least }\end{array}$ & $\begin{array}{l}\text { 1) A patient decides a person to whom he makes a message book. } \\
\text { 2) The patient talks about the person such as impressive memories with an interviewer. } \\
\text { 3) The patient talks what he wants to tell to the person. } \\
\text { 4) The patient or the interviewer make a message book including messages and drawing with arts. } \\
\text { 5) The patient hold the message book. } \\
\text { The patient decide whether he passes or hold it. }\end{array}$ \\
\hline
\end{tabular}

very low, so some of them took care of her. When a family member was out, she was very sad. A primary physician introduced her to a clinical psychologist and she proposed the study of "Making a Message Book", the patient wanted to make the book.

She knew that she was near death, however, she could not tell about death or anything after death. Her children took care of her, so she could not express weak points.

Session 2: The patient talked about her eldest daughter. Her eldest daughter was very active with high social skills. She remembered memories and added her emotions or words. The eldest daughter graduated college and worked in a company. When the patient found she had cancer, the eldest daughter found out a special hospital for cancer treatment. The patient added these words in the book (Figure 1): "I was very glad to assist you in club activities. I could have good time. I was helped from you (the eldest daughter). I was given power from you. You are my pleaser."

Session 3: The patient talked about her younger daughter. She was very calm and shy. She was sometimes absent from school. The patient was very worried, but thought positively. She took her on trips to various places. The younger daughter was a good musician, and the patients loved to watch her play her music. The patient talked these words in message book:

"You are shy, but you can do well, please live your life how you choose."

Session 4: The patient talked about her husband. He was true to himself and tender. She and her husband used to go on trips. He played with the children and helped raise them when the children were small. When the children became adults, only the two daughters and the patient talked. She regretted that. He took care of her after having this illness. She added these words:

"It was great pleasure for us to congratulate you at your retirement. I expressed thanks at heart."

Session 5: The clinical psychologist made a Message Book after the interview; she was very happy. After about 10 days, she was dead.

Session 6: After the patient's death, the elder daughter called the interviewer. She said:

"Did my mother know that she was going to die? When mother consulted her grave, I did not hear her words. I should have heard her words much more."

\section{Case 2}

Patient B: A patient B was in the general hospital. She was 70 years old. She was in a hospice ward in a general hospital. She had a daughter and a husband, and she greatly loved her grandchildren.

Procedure: Since she had high physical strength and was able to move herself, she positively participated in the study. She talked about herself and wrote down messages with drawings. She agreed to

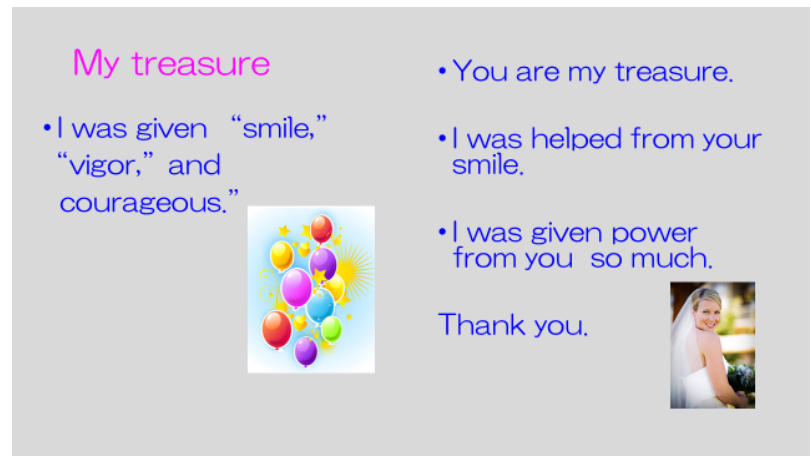

Figure 1. The patient's words in the message book.

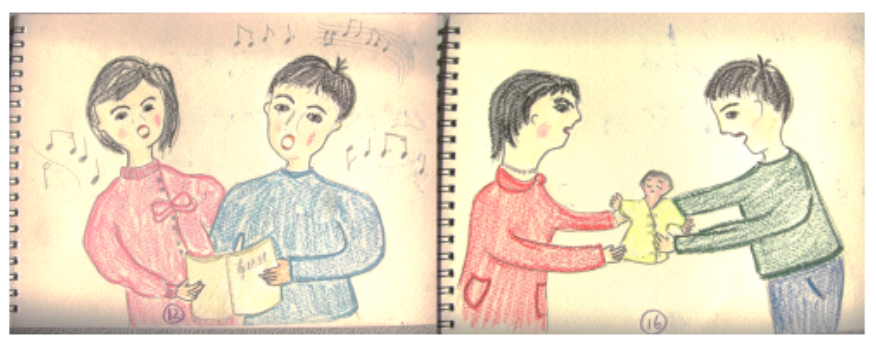

Figure 2. Sample of a message book.

participate in the research. The patient and the clinical psychologist met three times, once a week and performed "Making a Message Book."

Session 1: Patient B talked about her life from her college years. She was very active and she participated in various social activities. After she graduated from college, she worked for a long time at nursing homes and began volunteer activities. She said:

"Until now I worked for other people, but I feel that I found importance of my life and family. My family tries to make an effort for me to live, and I think that I have to live. I want to leave this message to my grandchildren."

Session 2: The patient talked to the interviewer, drawing a picture. She talked about her perception of life and death. She said the following: "I conducted what I wanted to do. I have no regrets in my life. Everyone dies, sometimes early and sometimes late. I am all right because I can say thanks and goodbye to many people. I was confused in my decision about chemical treatment. Since I can make this book, I think that the decision was all right. I don't know how long I can live, but I will live as much as possible.

Session 3: She completed the message book with color. She told a story. In the story, a baby, Hana, is hidden in somewhere like in a leave or shell. A mother and a father sang a song, then Hana was born. Hana was born to the present mother and father. Thank you for being here. She said, "Hana can't understand my existence, but when she grows, she will recognize the series; grandmother, her parent, and herself. She recognized the existence of the grandmother. I wanted to make the 
book to tell her that grandmother always watching over you (Figure 2)."

\section{Discussion}

In case 1 , although the patient wanted to talk about her near death experiences and something after death, she could not talk about her death or anything after her death because her family members took care of her sincerely, and they did not accept her death and would not talk. In this situation, she could express her emotions or thoughts by "Making a Message Book." She was relaxed after finishing the book, and performed her role as the grandmother. Then it might be contribute to promote a peaceful death.

In case 2, the patient recognized her near death and she wanted to talk about relationships among families. It is the realization of the theory of generativity by Erikson [4]. These two cases may show the utility of this approach for terminally ill cancer patients.

Dignity psychotherapy is one of the most effective psychotherapies for elevating spiritual well-being, with dignity based on generativity by Erikson [4]. However, sometimes the method of the procedure may be hard to participate in with this therapy, because terminally ill cancer patients need to talk about their lives to important persons. The patients need to accept their death and participate to make a legacy. On the other hand, "Making a Message Book" is also based on generativity, but the method may be moderate, using messages and art. Art therapy is useful for people to describe their emotions or thoughts nonverbally [5]. That is, "Making a Message Book" may be a much more moderate method than Dignity psychotherapy (2005).

As a limitation, it is a pilot study and the number of participants was too small. The method requires much more structure.

\section{References}

1. Miyashita M, Sanjo M, Morita T,Hirai K, Uchitomi Y(2007) Good death in cancer care: a quantitative study. Ann Oncol 18: 1090-1097.[Crossref]

2. Chochinov HM, Hack T, Hassard T, Kristjanson LJ, McClement S, et al. (2005) Dignity therapy: novel psychotherapeutic intervention for patients near the end of life. J Clin Oncol 23: 5520-5525.[Crossref]

3. Chochinov HM, Kristjanson LJ, Breitbart W, McClement S, Hack TF, et al. (2011) Effect of dignity therapy on distress end pf life experience in terminally ill patients: a randomized controlled trial. Lancet Oncol 12: 753-762.[Crossref]

4. Erikson E (1950) Childhoodand Society New York: W.W. Norton and Company.

5. Nainis N, Paice JA, Ratner J, Wirth JH, Lai J, et al. (2006) Reliving symptoms in cancer: innovative use of art therapy. J Pain Symptom Manage 31: 162-169.[Crossref]

Copyright: (C2016 Ando M. This is an open-access article distributed under the terms of the Creative Commons Attribution License, which permits unrestricted use, distribution, and reproduction in any medium, provided the original author and source are credited. 